\title{
The influence of informal institutions on informal sector entrepreneurship: A Study of Nigeria's Hand Woven Textile Industry
}

\begin{abstract}
Isaac A. Ogunsade and Demola Obembe

This paper draws on the institutional theory framework to explore the prevalence of entrepreneurship in the informal economy in Nigeria. An interpretive approach was taken in analysing open-ended interview data collected from twenty-six entrepreneurs in the hand woven textiles industry in the south western region of Nigeria. Our findings show that beyond regulatory burden or survivalist economic necessity, the enterprise culture in the Nigerian informal economy is determined by value-driven criteria of socio-cultural and normative environment that constitute part of the cognitive process of entrepreneurial emergence in a typical institutional context.
\end{abstract}

Key Words: Informal sector; Institutional environment; Entrepreneurship; Culture; Africa

\section{Introduction}

Recent studies reveal the prevalence of the informal economy and how a greater percentage of entrepreneurship in the developing economy operates informally (Bruton et al., 2012; Webb et al., 2012; Gurtoo and Williams 2011). The informal sector in Africa is primarily dominated by self-employment in unregulated and/or unmonitored markets, yet it contributes significantly to the gross domestic product (GDP), supply of labour force and to the economic growth particularly in Sub-Saharan Africa. (Aidis et al., 2006; Evans et al., 2006; Gurtoo 2009; Llanes and Barbour 2007; Williams 2006, 2011). The important contribution of the informal sector as an avenue for business incubation and basis for poverty alleviation within local communities and nations in general cannot be over emphasized. For instance, USAID studies in developing economies such in Asia, Latin America and Sub-Saharan Africa revealed that self-employment accounted for $59 \%, 60 \%$, and $70 \%$ of informal employment respectively (USAID, 2006). Similarly, the International Labour Organization observed that the share of the informal economy for non-agro allied work force account for about $80 \%$ in Africa.

Despite the important role of informal activities to the mainstream economy, in terms of the opportunities it offers to women and the vulnerable youth population (Portes and Haller, 2005), there exists little theoretical underpinning (Webb et al., 2012) and empirical research (Bruton et al., 2012) particularly within the scholarly domain and at the individual level to explain the nature and specific drivers of entrepreneurship and venture creation in the informal economy. Though factors such as regulatory burden and economic necessity have been advanced as the determinants of entrepreneurship in the informal sector, we agree with the view that the sociocultural context where this economic behaviour is found is very important in understanding the pervasiveness of this sector (Williams, 2006, 2009)

In this paper, we take the view that a holistic consideration of the normative, regulatory, and cultural cognitive environment will give a deeper understanding of drivers or determinants of informal economic activity in the sub-Saharan Africa. Consequently, we argue that the prevalence of informal enterprises in Africa should not only be limited to the inadequate regulatory structure or survivalist economic necessity, but also the normative 
and values driven socio-cultural dimension of the institutional environment where it is found. As Gerxhani (2004) asserts, many self-employed individuals choose to participate in the informal economy due to their experience of greater autonomy, flexibility and freedom than in the formal economy. Therefore, in this paper, we focus our attention on the prevalence and determinants of local entrepreneurs who started their ventures without registering their businesses with regulators for tax purposes. Specifically, we explored how the dimension of the institutional environment determines the proliferation or business creation in the informal economy.

The institutional environment comprising of the regulative, the normative and cultural cognitive environments (Scott, 2001), offers a valuable paradigm through which the determinants of, and level of entrepreneurial activities outside the formal or regulatory boundaries can be understood. It not only provides a suitable lens and increases our understanding of how prevailing cultures and values, determine modes of entrepreneurial engagement, it offers a causal link to capture and explain different macroeconomic outcome in terms of "necessity or opportunity" and the motivation of individual entrepreneur to start a new venture in the formal or informal sector. Thus, by applying institutional theory to evaluate determinants of entrepreneurship in the informal economy, the study accomplishes two objectives; first, it explores how institutional context determines entrepreneurship in the informal economy, and secondly it emphasizes the role of informal institutions in influences the prevalence of the informal economy.

\section{Theoretical Background}

\section{The informal economy in Sub-Saharan Africa}

Although academic research in entrepreneurship has grown rapidly over the decades, a concise definition or coherent paradigm for entrepreneurship is yet to emerge (Wiklund et al., 2011). Low and Macmillan, (1988) however, pointed out that the definitions, and concepts of entrepreneurship have been subjects of various debates and interpretation particularly, due to the diverse and interdisciplinary nature of the subject matter. In a similar vein, Godfrey (2011) noted that, existing definitions for entrepreneurship in the informal sector has also suffered a lack convergence around a unitary construct. Nonetheless, despite the many definitions of entrepreneurship in the informal economy there are common views. First, Entrepreneurial venture occurs at the nexus of individuals, opportunities and environments (Shane and Venkataraman, 2000, Gathner, 1985) and secondly informal entrepreneurship could be driven out of necessity or opportunity (Hughes, 2006). These common views have not only provided scholars with a conceptual foundation for understanding, measuring and defining entrepreneurship in the informal sector, but have made possible the emergence of a theoretical framework to understand and explain the diverse nature of entrepreneurship (Godfrey 2011).

The idea of informal economy was first introduced by Hart (1973). However, the construct have been described differently by scholars, expressions like, hidden enterprise, shadow economy, unorganized sector unregulated economy, irregular economy, unobserved economy have been associated with its definition (Webb et al., 2012). Also, phrases like "black market" "off the book or under the table" have been used to describe its activities. A review of literature on the informal economy suggests that entrepreneurship in the informal 
sector has been defined from different perspectives and levels of analysis (Godfrey, 2011). For instance, macro level determination such as, government regulation, tax issues, social security, legal policy framework. Others include skill, knowledge and education, human resources and capital.

Webb et al., (2012) define the informal economy as economic activities that are outside of formal institutional boundaries, that is illegal but yet legitimate. On the other hand, LaPorta and Schleifer (2008) in their definition categorize entrepreneurial activities in the informal sector as the unrecorded or unofficial economic activity carried out by either registered or unregistered firms and hidden for tax purposes. In another view, informality is also defined as a reaction, or defiance and an attempt to circumvent government regulatory control (Nwabuzor 2005). Despite the lack convergence around a unitary construct, a general agreement is that informal economy represents economic activities in sales, production and services that are not recorded or declared for social security and other tax purposes at the time it ought to be declared (Williams 2006; European Commission 2007).

Consequently, in this paper we view informal entrepreneur as all legitimate economic activities, and services that are not regulated or are insufficiently covered and recorded for tax purposes by formal institutional arrangements (e.g. Street vendors and other selfemployments in small unregistered enterprises). It is important to clarify that, our conception of informality excludes criminal economy (ILO, 2002) and does not cover illegitimate or illicit trading of goods and services considered as criminal (Smith and Christou, 2009). For example, undeclared profit or earnings from prostitution, pimping, drug trafficking, human trafficking, internet fraud etc. Therefore, for the purpose of this research, informal sector is characterized as visible trade and services which though not legal in the strict sense of business registration and taxes, but engage in the production and distribution of lawful goods and services, having share in the market economy. They include creative small business entrepreneurs, self-employed and street vendors in the production and distribution of goods and can serve as incubator for big business possibilities as well as transition into formal economy.

\section{Institutional perspective and the nature of the informal economy in sub-Saharan Africa}

Most informal sector in sub-Saharan Africa are dominated by microenterprises or selfemployment businesses that operate in clothing or apparel business, retail shops, traditional medicine, metalwork and building construction, hairdressing and tailoring services. These businesses have less than ten employees, and mainly are not registered or licensed and they are unregulated by government-informed official tax payment (Pretes, 2002). The pervasiveness of these socio-economic activities has been a subject of debate. However, contemporary institutional model has been engaged by scholars to examine socio-economic behaviour as well as micro or macro interaction of global phenomenon. According to Scott (2001), institutional theory enquires as to how elements within the social structure are created, developed, adapted and disused. Scott (2001) and North (1990) also use institutional theory to explain the processes through which certain rules, routines, norms and schemas impact behaviour and activities within the institutional environment. However, the existing studies reveal that entrepreneurship in the informal sector are driven by industry condition such as expense, cost of registration, risk reduction and other regulatory 
burden associated with setting up business in the formal economy (La Porta et al, 1999). Nevertheless, other scholars have suggested that entrepreneurs operating in the informal economy do not choose to but are pushed into informal sector by inefficient public institutions and other macro-economic conditions as a form of survival strategy (Gallin, 2001; Hughes, 2006). This implies that, necessity more than opportunity determines the operators in the unregulated economy.

Literature on institutional theory has grown in its adoption and analysis of entrepreneurial activities and venture creation decision. An overview of the institutional perspective suggests that institutional environment influence individual and firm's behaviour. Moreover, individual motives or actions toward venture creation are to an extent, influenced by the stimulus provided within the macro and the micro institutional context (Gartner, 1985; Busenitz et al., 2000). With regards to the prevalence of the informal economy, the institutional environment presents a complex and unique combination in the entrepreneurial process of venture creation (Gartner, 1985). In particular, the works of Gartner (1985), Baumol (1990), North (1990), Scott (2001) and Lumpkin and Dess, (2001) have greatly highlighted the relationship between the environments and entrepreneurship development. As such, a key element in the relationship between the institutional context and entrepreneurship in the informal economy is that the institutional environment impacts the nature and mode of entrepreneurial activities within the economy or society (Welter and Smallbone, 2011).

According to the institutional environment theory, individual entrepreneurs operate in and respond to the environment. For example, North (1990) describes institutions as 'rules of the game' that define and limit the opportunity and choices available to individuals within a particular social context. Scott (2001) suggests that the level and modes of entrepreneurial activity are affected by the surrounding culture and by legal rules. Institutional environment plays a critical role in entrepreneurial process and venture creation, and it could be argued that, institutions determine certain economic behaviour and choices which impacts on entrepreneurial activities within the economy or society. In essence, Institutions act as a collection of structures and system that provide stability and meaning for entrepreneurial choices or behaviour. However, using Scott's (2001) proposition that institutional environments consist of regulatory, cultural-cognitive, and normative aspects, these three environments will be taken to illustrate the nature and the determinants of entrepreneurship in the informal economy in the south western Nigeria.

\section{Regulatory institutional environment}

The formal institution also known as the regulatory component of a country's institutional environment consists of laws and rules that stimulate certain types of behaviours and constrain others (Scott, 2001). Beyond government regulation and laws, the regulatory environment in Nigeria also includes trade policies, land allocation, taxation policies, infrastructure development, social security, business registration, licensing requirements as well as other macroeconomic policies that provide support for new businesses, reduce the risks for individuals starting a new venture, and enable entrepreneurial efforts to acquire venture capital. 
Recent studies reveal that supportive regulatory environment for small business development is lacking in most developing countries and that this neglect or discrimination could be responsible for the growth of informal sector (Tesfashew, 1992). Nwabuzor's (2005) conception of informality as a reaction, or defiance and an attempt to circumvent the burdensome government regulatory control, absence of transparency and accountability of government institutions represents a typical scenario in sub-Saharan Africa. Particularly, in an environment where basic infrastructure and social amenities are lacking, and where official corruption thrives, the consequence is that such environment produces a noncompliance culture and a pervasive set of entrepreneurs operating in black market or off the book (Hariss-White, 2010).

\section{Cultural and Normative Environments}

Scott (2001) describes the normative and cultural cognitive pillars as the informal environment. The crucial role of culture in the development of entrepreneurship is emphasized by the fact that cultural and normative environments play an important role in the determination of the societal norms, beliefs, values and assumptions that are shared within the society (Hofstede, 2001; Wennekers, 2006; Welter, 2005). For instance, in their analysis of the determinants of entrepreneurial emergence in a typical sub-Sahara Africa, Madichie et al., (2008) found that the prevalence of entrepreneurship among the Nnewi people in the eastern part of Nigeria is driven by individualism and apprenticeship in the "Afia Olu" and "Ikwu Aru" cultural festival. Similarly, the 'Aso oke' culture of the Yoruba in western Nigeria date back as far as the late 19th century where the image of an 'Aso oke' weaver within the local environment was seen not only as a representation of personal business success, but as an avenue promoting apprenticeship. Davidsson and Wiklund (1995) assert the crucial role of culture in the determinant of regional or national supply of entrepreneurship. Specifically, a supportive or performance cultural environment defines goals and shows the levels at which society or individuals perceive opportunities, as well as admire the values of autonomy, risk taking and innovation. The normative dimension also affects the general societal orientation in terms of its resilience, creativity and legitimacy for entrepreneurial emergency in the informal economy. Lee and Peterson (2000) posited that cultural values and norms will most likely converge or conflict with the capacity of a society to develop and support entrepreneurial rate.

\section{The cognitive environment}

The cognitive environment refers to cognitive structures; values, perceptions, and socialization activities that are prevalent in a particular society or among groups of people, and whose values are acquired and manifested in both conscious and unconscious behaviours (Hofstede 1980; 2001). It also consists of the mind-set and social knowledge that are shared by the people within a society, region and country. This shared perception constitutes the nature of reality and the lenses through which meaning is interpreted (Scott 2001; Hoffman et al., 2002). The cognitive dimension argument is that, similar to culture, the cognitive structures; the mind-set or thought pattern could stem from an individual social environment and through different stages of the socialization process in the institutional environment. Hoffman et al., (2002) concluded that cognitive institutions are socially constructed assumptions and interpretation given to particular phenomena. Thus, in 
relation to entrepreneurship in the informal economy, the cognitive component of the institutional environment relates to how potential venture opportunity is perceived, how government regulation and innovative orientation is interpreted, the social status for entrepreneur, and the fear or experience of failure associated with launching a new venture in the government-led regulated economy.

Both Shapero and Sokol (1982) and Krueger (1993) argued that perceived desirability, perceived feasibility, and propensity to act are associated with entrepreneurial cognitive perceptions and studies lend support to the notion that the cognitive, the regulatory and cultural environments impact the level and modes of entrepreneurial activity found within a society. For instance, assessment of the cognitive environment in South Africa reveals that entrepreneurial engagement is restricted by scarcity of skills, and knowledge to start or grow their business (Urban et al., 2005). Similarly, Lacobucci and Rosa (2010) observed that perceptions of entrepreneurship in Uganda affect occupational choice, as a result of specific status ascribed to a given occupation. Spencer and Gomez (2004) further submitted that the cognitive burden that aspiring entrepreneurs are confronted with, can stop actions oriented towards aspiring and acting entrepreneurs, and should be lower for increased engagement in the formal sector by nascent and small scale entrepreneurs. We thus attempt to understand the specific role of the cultural-normative and cognitive environments in impacting the proliferation of entrepreneurship in the informal economy.

Overview of the literature suggests that the institutional context through its regulatory, normative and cultural cognitive affects economic behaviour and mode of entrepreneurial activities in the informal sector. The important elements of the regulatory environment that could affect activities in the informal economy are the inadequacy in the regulatory environment which includes gaps in the national accounting policy that do not adequately account for all economy activities, the absence of government support for small businesses in terms of registration and tax burden for new business. For example, institutional difficulties in the process of registering business and delay getting licenses. Also, lack of provision of basic amenities like power supply, water, road, affordable market stalls, grants and loan, a conducive environment devoid of corruption, and other social security that may reduce business risk may contribute to noncompliant or defiant behaviour of entrepreneurs within the informal sector. Within the normative and cognitive environment we assume that culture plays an important role in the supply of entrepreneurship activities and also that the culture of a society or group affects the general orientation and its value system. A society that values independence and creativity tends to promote and facilitate entrepreneurial event, which can be achieved either through non-compliance culture to regulatory framework or the informal mechanism of trust, social capital or network which facilitates the mobilization of resources for start-up fund.

A fundamental objective for the study is to identify the drivers of entrepreneurship in the formal economy in Nigeria, and to explore which of the dimensions of the institutional environment determine the prevalence of entrepreneurship in the informal economy. In view of the foregoing, we explore two main research questions:

1. What motivates or drive entrepreneurship in the informal economy in Nigeria? 
2. To what extent is the regulative, normative and cognitive environment influence the prevalence of this sector? In the subsequent section we explain the methods of data collection and the presentation of our findings.

\section{Methods}

Operationally, this paper views informal entrepreneur as all legitimate economic activities and services that are not regulated or are insufficiently recorded for tax purposes by formal institutional arrangements. To understand the institutional context and the underlying reasons for entrepreneurs operating in the informal economy, we chose to collect data using primary data collection method as activities in the informal economy are not recorded. We adopted an exploratory, qualitative research design, which is suited to gaining deeper understanding and determining the nature of a particular phenomenon or problem that is poorly understood (Yin, 2003; Saunders et al, 2007). We investigated 30 entrepreneurs operating in 'Adire' and 'Aso oke' hand woven textiles industry in Itoku south western Nigeria. Specifically, we sort to know if the inadequacy in the regulatory environment account for non-compliance culture and a prevalent of businesses operating off the book or in the informal economy? And the specific role the prevailing socio-cultural environments play in impacting the proliferation of entrepreneurship in the informal economy in the south western Nigeria?

\section{Study Setting}

This study covers south western Nigeria. Our choice of this geographical area in Nigeria is based on the fact that Adire and Aso Oke manufacturer have big market concentration in many south western parts of Nigeria such as, Itoku (in Abeokuta) Gbagi (in Ibadan), and Akerele (in Lagos) just to mention a few, these clothe makers are known to have been successful in there trading activities. We chose to investigate Adire and Aso oke hand woven textiles industry in Itoku Abeokuta south western Nigeria because of the diversity characterizing the community, and also the market have an established local association or union, this local association are not formal in the real sense of government or officially registered trade association with seals or capacity to seek bank loan on behalf of members, but they are still organized to the extent to which they can control prices, as well as the entry and exist of new traders or producers.

For a number of reasons, it was difficult to gain access for the purpose of interview. First, Adire and Aso Oke production have the capacity to serve as a springboard for skill accusation, thus possess a relative amount of innovation in terms of fine arts, and other trade secrets that are involved in the production process. Second, most respondents displayed apathy and reluctance to participate in the study due to the sensitive nature of the topic.

This obstacle was however overcome, through assistance from an insider even at then, the researcher had to assure the participants that the study was just for academic purpose and not government sponsored undercover agents as one the respondents specifically confronted the researcher with this question. However, we did our interview with the expectation that there could be some measures of distortions. The majority of 
entrepreneurs in the informal economy operate on a neighbourhood basis where they erect shops or shed for their operations. The individual interviews took place within the vicinity of the production centre.

\section{Data Sources/Data Collection}

Multiple data sources are important to qualitative research. Our source of data comes from the information we gathered from the field from both the trade association and the interviews granted during the study. Literature and other informal observation within the environment of our study also informed our research. The population for study comprised of owner managers or founders in hand woven textiles industry in south western Nigerian. Using a combination of purposive and snowballing sampling techniques, a total of 38 founders were engaged, a sample of 20 founders were identified through their trade association and subsequent 18 participants via snowballing where a participant nominated one or two other participants for the purpose of the study.

Our data collection took place between December 2014 and January 2015. We began with the collection of background information that captured the age of the business and that of the founders, the educational qualification, if business is registered, unregistered and if trading activities are off the books. The scope of the interview was equally designed to elicit wide ranging reflections into why the respondents operate in the informal economy, their motivation for setting up business and their perception of cost and source of capital. In our opinion, a valuable investigation into activities in the informal sector should consider not only the regulatory environment or how people choose to structure their transactions, but also recognize that many choose this structure based on conscious value-driven criteria of socio-cultural and normative environment rather than economic necessity. We felt this was best accomplished through informal conversations facilitated by open-ended non-leading questions.

Apart from basic profile questions, participants were asked about trading in the informal economy (off the books), the type of business, how long they have been in business, business ownership, and if their trading activities were recorded. Also, we sort known factors within the institutional environments that determine or encourage this behaviour. For example, we investigated if their business is registered, and if not when they plan to do so. We also tried to know the nature of their business, and the source of capital, the perceptions and motives for operating in the informal economy. Each interview took between 40 and 45 minutes, and was guided by the following three main questions:

1. Briefly describe why you prefer to operate in the informal economy rather than formal economy that is open to government regulation?

2. Why specifically, do you prefer operating off the book?

3. Describe factors in the institutional environment (regulatory, socio-cultural) that made it easier, or difficult, for your trading activities. For example, raising of capital, social security, and labour.

We took permission to record the conversation, which was also complemented by note taking. In the quest for validity, we adopted respondent feedback, probes and clarification 
where necessary (Taylor and Bogdan, 1988). The local language (Yoruba) was used for the purpose of the interview and transcription done in English.

\section{Data Analysis}

Our analysis involved the transcriptions of all interviews from local language into English. The transcribed data were read and reviewed, in the quest for validity, we cross examined the transcribed data with the translation. A fundamental objective for the study is to uncover the determinant of entrepreneurial activities in the informal economy in Nigeria, and to explore to what extent the regulative normative and cognitive environment influence the prevalence of this sector. Following Charmaz (1995), a thematic analysis was adopted. We developed themes in line with objectives and theoretical framework of our study, emerging themes were identified and analysed. By means of manual coding we adopted different colours and fonts to categorize and analyse our themes using a theory led coding rule following Scott's (2001). We coded all instances where the owner managers of the Aso oke and Adire makers made mention of informal or formal institutional context as impacting their trading activities in the informal sector. Furthermore, as we progress with our analysis we incrementally refined and further categorized the codes into three institutional themes using direct quotation of respondents. For example, we coded respondent statements regarding to source of capital from family or network into the normative environment. Also, as values, norms, practices, apprenticeships, and independence were coded under the normative or cultural environment, skills, knowledge and set -up of apprentices were coded under the cognitive environment. Furthermore, statements regarding government activities such as taxes, loans or grants, fines, and local rates were coded under regulative environment.

In the course of our interview we discovered that 4 participant were either not the founder of the business or were reluctant to give information vital to the study, hence they were excluded from our presentation. In total 26 interviews were satisfactorily carried out with 16 Adire (tie and dye) and 10 Aso Oke (traditional weave) makers.

Of the twenty-six entrepreneurs interviewed, 16 were involved in the production of Adire (tie and dye) and 10 Aso Oke (traditional weave) makers. Our interviewees' age ranges between (36-55 years). Twenty interviewees were women, while six were men. This reveals that the informal economy is dominated by women. The age of their existing business or venture were between 10 and 30 years, indicating strongly that Yoruba cloth weaving tradition is one of the most popular and prosperous textile traditions in West Africa. In twenty six production shed or location that we carried out interviews, each interviewee had as many as 3 to 6 apprentices in which upon graduation will also find other locations to start the trade. However, given that lack of formal education majority of the business owner we interviewed did not bother to register their business. As Table 1 reveals, more section of the market did not register their business and trade wholly off the book. 


\begin{tabular}{|c|c|c|c|c|c|c|c|c|c|c|}
\hline $\begin{array}{l}\text { Participant } \\
\text { Code }\end{array}$ & Business type & $\begin{array}{l}\text { Business } \\
\text { Age } \\
\text { (year) }\end{array}$ & OM Age & $\begin{array}{l}\text { OM } \\
\text { Gender }\end{array}$ & $\begin{array}{l}\text { Business } \\
\text { Ownership }\end{array}$ & $\begin{array}{l}\text { Educational } \\
\text { Level }\end{array}$ & $\begin{array}{l}\text { Registered } \\
\text { but } \\
\text { Trading off } \\
\text { the Book }\end{array}$ & $\begin{array}{l}\text { Unregistered } \\
\text { and Wholly } \\
\text { off the Book }\end{array}$ & $\begin{array}{l}\text { Number } \\
\text { Apprent } \\
\text { ice }\end{array}$ & Source of Capital \\
\hline OM 1 & $\begin{array}{l}\text { Hand woven } \\
\text { Aso Oke }\end{array}$ & 20 & 45 & $\mathrm{~F}$ & $\begin{array}{l}\text { Family } \\
\text { Business }\end{array}$ & Nil & Nil & UTOB & & 5 Family and social network \\
\hline OM 2 & Aso Oke & 10 & 37 & $\mathrm{~F}$ & Founder & pry & Nil & UTOB & 4 & 4 Family and social network \\
\hline OM 3 & Aso Oke & 15 & 41 & $\mathrm{~F}$ & $\begin{array}{l}\text { Family } \\
\text { Business }\end{array}$ & pry & Nil & UTOB & & 5 Family and social network \\
\hline OM 4 & Aso Oke & 30 & 55 & $\mathrm{~F}$ & Founder & Nil & RTOB & Nil & 5 & 5 Family and social network \\
\hline OM 5 & Aso Oke & 25 & 47 & $7 \mathrm{~F}$ & $\begin{array}{l}\text { Family } \\
\text { Business }\end{array}$ & pry & Nil & UTOB & & 4 Family and social network \\
\hline OM 6 & Aso Oke & 12 & 42 & $\mathrm{M}$ & Founder & pry & Nil & UTOB & 3 & Family and social network \\
\hline OM 7 & Aso Oke & 10 & 40 & $\mathrm{M}$ & $\begin{array}{l}\text { Family } \\
\text { Business }\end{array}$ & Secoundary & RTOB & Nil & & 5 Family and social network \\
\hline OM 8 & Aso Oke & 26 & 43 & $\mathrm{~F}$ & Founder & pry & Nil & UTOB & 3 & Family and social network \\
\hline OM 9 & Aso Oke & 25 & 37 & $7 \mathrm{~F}$ & Founder & Secoundary & Nil & UTOB & & 4 Family and social network \\
\hline OM 10 & Aso Oke & 18 & 38 & $\mathrm{M}$ & $\begin{array}{l}\text { Family } \\
\text { Business }\end{array}$ & pry & Nil & UTOB & & 3 Family and social network \\
\hline OM 11 & Adire Tye \& Dy & 10 & 46 & $\mathrm{~F}$ & $\begin{array}{l}\text { Family } \\
\text { Business }\end{array}$ & pry & Nil & UTOB & 5 & 5 Family and social network \\
\hline OM 12 & Adire Tye \& Dy & 15 & 36 & $\mathrm{~F}$ & $\begin{array}{l}\text { Family } \\
\text { Business }\end{array}$ & Secoundary & RTOB & Nil & & 5 Family and social network \\
\hline OM 13 & Adire Tye \& Dy & 20 & 45 & $\mathrm{~F}$ & Founder & Nil & Nil & UTOB & 5 & 5 Family and social network \\
\hline OM 14 & Adire Tye \& Dy & 20 & 48 & $\mathrm{M}$ & $\begin{array}{l}\text { Family } \\
\text { Business }\end{array}$ & Secoundary & Nil & UTOB & 5 & 5 Family and social network \\
\hline OM 15 & Adire Tye \& Dy & 17 & 38 & $\mathrm{~F}$ & $\begin{array}{l}\text { Family } \\
\text { Business }\end{array}$ & pry & Nil & UTOB & & 4 Family and social network \\
\hline OM 16 & Adire Tye \& Dy & 10 & 36 & $\mathrm{~F}$ & Founder & pry & Nil & UTOB & 3 & Family and social network \\
\hline OM17 & Adire Tye \& Dy & 25 & 50 & $\mathrm{~F}$ & $\begin{array}{l}\text { Family } \\
\text { Business }\end{array}$ & Nil & Nil & UTOB & 5 & 5 Family and social network \\
\hline OM18 & Adire Tye \& Dy & 22 & 41 & $\mathrm{M}$ & $\begin{array}{l}\text { Family } \\
\text { Business }\end{array}$ & Secoundary & Nil & UTOB & 4 & 4 Family and social network \\
\hline OM19 & Adire Tye \& Dy & 13 & 36 & $\mathrm{M}$ & $\begin{array}{l}\text { Family } \\
\text { Business }\end{array}$ & pry & Nil & UTOB & 4 & 4 Family and social network \\
\hline OM20 & Adire Tye \& Dy & 19 & 39 & $\mathrm{~F}$ & $\begin{array}{l}\text { Family } \\
\text { Business }\end{array}$ & Secoundary & Nil & UTOB & 6 & 5 Family and social network \\
\hline OM21 & Adire Tye \& Dy & 13 & 46 & $\mathrm{~F}$ & $\begin{array}{l}\text { Family } \\
\text { Business }\end{array}$ & Higher Edu & RTOB & Nil & 6 & 5 Family and social network \\
\hline OM22 & Adire Tye\& Dyє & 26 & 44 & $+F$ & $\begin{array}{l}\text { Family } \\
\text { Business }\end{array}$ & pry & Nil & UTOB & & 5 Family and social network \\
\hline OM23 & Adire Tye \& Dy & 11 & 45 & $\mathrm{~F}$ & Founder & Higher Edu & RTOB & Nil & 4 & 4 Family and social network \\
\hline OM24 & Adire Tye \& Dy & 10 & 39 & $\mathrm{M}$ & $\begin{array}{l}\text { Family } \\
\text { Business }\end{array}$ & Secoundary & Nil & UTOB & & 5 Family and social network \\
\hline OM25 & Adire Tye \& Dy & 20 & 45 & $\mathrm{~F}$ & $\begin{array}{l}\text { Family } \\
\text { Business }\end{array}$ & Secoundary & Nil & UTOB & 4 & 4 Family and social network \\
\hline OM26 & Adire Tye \& Dy & 22 & 47 & $7 \mathrm{~F}$ & $\begin{array}{l}\text { Family } \\
\text { Business }\end{array}$ & pry & Nil & UTOB & & 5 Family and social network \\
\hline
\end{tabular}

Table 1: Field study, southwestern Nigeria hand-woven textile informal economy

\section{Empirical Findings}

The hand woven textile industry represent an age long Yoruba weaving tradition and an important source of livelihood for the local community especially women. Though an informal segment, it represents a hidden enterprise culture (Williams, 2006) that contributes greatly to economic prosperity, labor force, as well as the gross domestic product of not only the local community but also the larger economy. Findings also show that entrepreneurs in the informal sector lack voice and representation because they are 
largely small business or home based self-employment, with low education as can be seen in Table 1.

However, given a prior consideration to our research questions we examined and evaluated the institutional determinant and drivers of entrepreneurship in the informal economy particularly, in the south western Nigerian hand woven textile industry. We investigated the extent to which the regulative, normative and cognitive environments influence the prevalence of this sector.

In exploring regulative environments, we asked the respondents to tell us why they prefer to operate in the informal economy rather than formal economy that is open to government regulation, we considered if the motive for operating informally was because of the regulative procedures or difficulties associated with business registration. We also considered tax related issues, as well as tax avoidance. For example, when asked the question why they prefer to operate in the informal economy rather than formal economy?

Many of the owners explained:

"To get government support is difficult, but I like the way am doing my business, I am not indebted to government and I am independent". (OM 10).

"I do not see any reason why I should register any business, it is easy for me to do my trading like this, after all I am just a small business owner, I think it is the big, big companies you ask all these questions". (OM 22).

When probed with further questions on tax related issues. Many of our participants disagreed to the tax evasion or avoidance reasons. Like the owners explained:

"You see my brother.....eeeeh local tax officials come here every month to collect fines, and all sorts of enh...levies. We don't even know what they do with the money" (OM 25).

"I do not think hum mm... because we do not register our business then we are running away from paying taxes. Everybody in this market pay local government people, we even pay more than the big companies, you know we do not really know how to read and write very well, this does mean that we don't have common sense" (OM 23).

Our findings thus, revealed that Adire textile manufacturer in south western Nigeria do not see the need or value of registering their business as well as trading in the formal economy. Their businesses operate off the book not necessarily to avoid government regulation or payment of taxes. Almost all our interviewees disagreed to tax related questions because according to them.

"Local tax officials come in every month to collect fines, we don't even know what they do with the money, our roads are bad, and electricity is a problem" (OM 01). 


\section{Normative and Cultural Cognitive}

With respect to the normative and cultural cognitive theme, we investigated the underlying values, norms and cultural orientation of the founder, and how social network or capital influences this behaviour. We also considered if survival to make ends meets determine the motive for operating off the books. We also considered what factor in the institutional environment made it easier or difficult for trading activities and if the motive for operating informally is to make ends meet.

When we asked the question for their source capital; if they get grant from the local government or the bank, responses suggested an inherent difficulty in accessing government aid:

"There is no way an individual like me will qualify or be able to raise government loan or money through the bank, we get money from (Esusu) contribution from families and different society that an individual belong for start-up", (OM 7)

"You cannot get money from the local government; we get money from contributions (network of association) and family members". (OM15)

"To get government support is difficult, but I like the way am doing my business, I am not indebted to government and I am independent". (OM10)

"I want to own my own business and not work for anyone that is why I acquired the skills as an apprentice"

Furthermore, from our analysis we discovered that majority of the entrepreneurs in the hand woven textile see their business as more of a family tradition, skills and culture that were passed onto them from their great grand father or mother. Some producers that we interviewed narrated how the Adire has been an indigenous trade before the pre-colonial period when threads and cloth were produced by the local people before the boom in importation of foreign clothes.

"I have been in this business for more than twenty years, in fact it was handed down to me by my mother before she died". "..The skills are in the family, it is like a daily activities I grew to know." (OM 17)

Further evaluating the normative environment, we also found that the importance of independence and apprentice culture. The apprenticeship culture, and the legitimacy that is attached to self-employment, is very strong. The apprentice culture present unique values, attitudes and cognitive factor that drive the start-up behaviour For instance, when we asked what factor in market environment that led to the proliferation of so many young entrepreneurs in the business? Many of the owners explained:

"Many of our girls are apprentice, you see like me, I have as many as 5 apprentices who work for me and also learn the secret of this trade, and when they stay and 
settle down to understand the techniques very well we help them with capital to set up their own business too." (OM 23)

"In the past 2 years, hummm... I have graduated or freed up to 6 boys and girls working for me and I have also taken another three, the fact is that this business required that you have people who can work and help you in the production process and after like three or four years of learning as well as working you, you then set them up to be their own boss". (OM 12).

"The small lady that occupied the second space toward the entrance trained under me. She is my girl and will always be because she is very good and we still maintain the family relationships" (OM 16)

Although previous studies have shown that regulations and burdensome registration process hinders formalization of enterprises in the informal sector (Desai, Gompers, and Lerner, 2003). Analysis of our findings suggests that within the western Nigeria environment, there exist a hidden enterprise culture that is embedded in a social network and a system that places high value on apprenticeship system and independence through small business start-up.

This social network which also includes the social capital represents the source of capital in the hand woven textile informal market in Nigeria. This source of capital has its root in family relations, associations, norms and culture of trust. The network facilitates and legitimizes enterprise culture that makes the prevalence of informal economy inevitable within this environment.

\section{Theoretical and practical Implications}

Our study align with the debate on the need for theoretical and empirical research to explain the nature and drivers of entrepreneurship in the informal economy (Webb et al., 2012; Bruton et al., 2012).

The study being explorative in nature adds to knowledge on the influence of the informal institutions on entrepreneurship in a number of ways. First, Using Scott's (2001) institutional theory provides a holistic framework by drawing on the regulatory, normative and cultural cognitive dimensions of institutional theory to explain the prevalence of these activities in sub-Saharan Africa, thus extending the existing study which tends to attribute informality to economic necessity and inefficient regulatory or national accounting system in explaining activities in the formal sector (Thomas et al; 2011).

Second, we examined which of the dimensions of institutional environment influence entrepreneurship in the informal sector in Nigeria. Our study found evidence that the informal institutions in the normative and cultural-cognitive environment have the strongest impact on the prevalence of informal economy. An important implication of this study is that the cultural and normative environments play a major role in influencing economic behaviour and prevalence of informality in the developing countries and particularly in Nigeria. Scott (2001:48) asserts that institutional environments are social structures; 
"schemas, rules, norms, and routines" that become established as influential guidelines for social behaviour. For example, the submissive apprenticeship culture has been a long time cultural practice of skill acquisition and self-employment common with this industry. These values are long lasting and deeply rooted in their everyday life and taken for granted. In twenty six production shed or location that we had interviews, each interviewee had as many as 4 apprentices which often are members of their families and in which upon graduation, these apprentices will also find other location to start the trade.

Third, this hidden enterprise culture ((Williams, 2006) is embedded in a social network, and facilitated through what is called reputation bonding and trust. A form of social capital that provides the start-up fund for most apprentices, which also provides other benefits such as supplies of inputs materials as well as customers. This assertion is consistent with Shapero and Sokol's (1982) position on the place of socio- cultural environment and individual value systems in the formation of new ventures. That is, when a society or social system supports and values creativity and independence by giving legitimacy to venture creation, that society is most likely to take opportunities within the environment that will lead to a pervasive entrepreneurial event. As the findings suggest, the perceived difficulty of respondents in dealing with the government and formal establishments in areas such as securing funds, and other hurdles in business start-up, invariably inclines individuals towards family ties in mobilizing resources which create further opportunity operating in an informal setup.

Empirically, based on the study of 26 entrepreneurs in the Hand Woven Textiles industry in the south western Nigeria, we have evidence to conclude that among many factors, such as the regulatory burden, policy neglect, and other inefficiencies from the regulatory environment contribute a small account for prevalence of entrepreneurial activities in the informal sector. The prevalence and persistence of small enterprise in the informal sector is borne out of the prevailing enterprise culture that is found in the socio-cultural environment of the Yoruba women in the southern part of Nigeria. The normative environment that valued and legitimized self-employment also encourage desires for independence. The desire for independence has been asserted by scholars to be an expression of cultural norms and social structures. The suggestion is that cultural dimension influences the general societal orientation and is deeply embedded in the functioning of the societal institutions, its norms, values, perceptions, and socialization (Hofstede 1980; 2001).

In addition, findings from our current research support the existing study, which submits that entrepreneurial activities in the informal economy are very important to the mainstream economy, in terms of the opportunities it offers to women and the vulnerable youth population. Though, be illegal as regard to formality but, the economy gap it fills in terms of poverty alleviation for the local community can be overemphasised

This study also offers important practical insights, as a policy implication, the government should recognize the need for the mobility or transition of this sector. We believe the enterprise culture is untapped, and needed to be earnestly looked into by the government. For instance, we found out that the Hand Woven Textiles industry in the south western Nigeria serve as a seed bed for skill acquisition and business incubator. Particularly, the industry generates employment for other classes of traders and end users. For example, the 
suppliers of synthetic dyes, cloths, caustic soda and other materials used in the production of Adire tie and dye. We also have the fashion designers and those that engage in tailoring, the artist and others in the production process.

Entrepreneurial activities in the informal sector are taken for granted by the government particularly the local government in the developing countries (Spring, 2009). We however, agreed with Ngoasong and Kimbu (2016) that government can bring the informal activities to formal sector despite the challenges of regulatory and institutional difficulties. We believe this can be achieved through regulatory supports and partnering with local trade association. The recognition, certification and accreditation of small trade association will afford opportunity for regulation, compliance as well as, sustainability of the enterprise.

While government has placed more focus on the formal sector, on the contrary nongovernmental agencies and big players in the formal sector see them as part of the market economy. For example, firms in the formal sectors like Coca-Cola, Nigerian Breweries etc.provide support for small retailers in the form of equipment which include fridges, and signs post for small retailers and distributors of their products in the informal market in Nigeria. Government particularly at the local level can support operators in the informal sectors or organized association of Aso Oke by providing capital, stall market, road network, van or vehicle loans and grant as well as other facilities that will have direct effect in promoting trade, expanding operators' businesses and at the same time bring them into formal sector where their impact on the society and economy of the locality can be greatly improved. These measures will be a win-win situation for the government, the traders and their association in the informal economy. In essence, a policy document to seriously look into to the activities of the informal entrepreneurs and small businesses as means of fighting the growing unemployed youth population in the informal economy in sub-Saharan Africa is urgently begging for attention.

\section{Conclusion}

Drawing on the insights of the institutional theory of Scott (2001) and thoughts of North (1990) and Baumol (1990) this paper posits that the prevalence of informal economy in SubSaharan Africa is not just a product of regulatory environment, but also the taken for granted culture of submissive apprenticeship and the cultural pattern or enterprise culture that is embedded in social network and a value system that places high value on independence through small business start-up.

We conclude that beyond the regulatory burden or survivalist economic necessity, the prevalence of informality activities is greatly determined by value-driven criteria of sociocultural and normative environment that constitute part of the cognitive process of entrepreneurial emergence in a typical institutional context. In sum, drawing on institutional theory to examine entrepreneurial activities in the informal economy, this study contributes to empirical and theoretical gap in the understanding of the prevalence of economy activities in the informal sector. The study suggests significant scope for future research on the nature of apprenticeship culture and social capital for small business start-up in Africa. Finally our study also opens up debate on family business and the policy implication on for transition of informal to formal economy. 


\section{References}

Aidis, R., Welter, F., Smallbone, D. and Isakova, N. (2006), "Female entrepreneurship in transition economies: the case of Lithuania and Ukraine", Feminist Economics, Vol. 13 No. 2, pp. 157-83.

Baumol, W. (1990), "Entrepreneurship: productive, unproductive and destructive", Journal of Political Economy, Vol. 98 No. 5, pp. 893-921.

Bruton, G. D., Ireland, R. D., \& Ketchen Jr., D. J. (2012). Toward a research agenda on the informal economy. Academy of Management Perspectives, 26(3), 1-11.

Busenitz, L., Gomez, C., and Spencer, J. W. (2000). 'Country Institutional Profiles: Unlocking Entrepreneurial Phenomena'. Academy of Management Journal, 43: 994-1003.

Davidsson, P. and J. Wiklund. 1995. "Cultural Values and Regional Variations in New Firm Formation." In Frontiers of Entrepreneurship Research. Wellesley, MA: Babson.

Desai, M., P. Gompers, and J. Lerner. 2003. Institutions, capital constraints an entrepreneurial firm dynamics: Evidence from Europe. NBER Working Papers No. 10165. Cambridge, MA: NBER.

European Commission (2007), Stepping Up the Fight against Undeclared Work, European Commission, Brussels.

Evans, M., Syrett, S. and Williams, C.C. (2006), Informal Economic Activities and Deprived Neighborhoods, Department of Communities and Local Government, London

Gallin, D. 2001. "Propositions on Trade Unions and Informal Employment in Time of Globalisation." Antipode 19 (4): 531-49.

Gartner, W. B. (1985). A conceptual framework for describing the phenomenon of new venture creation. Academy of Management. The Academy of Management Review, 10(4), 696.

Gerxhani, K. (2004), "The informal sector in developed and less developed countries: a literature survey", Public Choice, Vol. 120 No. 2, pp. 267-300

Godfrey, P. C. (2011). Toward a theory of the informal economy. Academy of Management Annals, 5(1), 231-277.

Gurtoo, A., Williams, C.C., 2009. Entrepreneurship and the informal sector: some lessons from India. Entrepreneurship and Innovation 10, 1-8.

Harriss-White, B. (2010). Work and wellbeing in informal economies: The regulative roles of institutions of identity and the state. World Development, 38(2), 170-183.

Hart, K., 1973. Informal income opportunities and urban employment in Ghana. The Journal of Modern African Studies 11 (1), 61-89.

Hoffman, A.J., Riley, H.C., Troast, J.G. Jr and Bazerman, M.H. (2002), "Cognitive and institutional barriers to new forms of cooperation on environmental protection: insights from project XL and habitat conservation plans", American Behavioural Scientist, Vol. 45 No. 5, pp. 820-845. 
Hofstede, G. H. (1980). Culture's Consequences: International Differences in Work -Related Values. Thousand Oaks, CA: Sage

Hofstede, G. (2001). Culture's consequences: Comparing values, behaviours, institutions and organizations across nations, Thousand Oaks: Sage Publications.

Hughes, K. (2006), "Exploring motivations and success among Canadian women entrepreneurs" Journal of Small Business and Entrepreneurship, Vol. 19 No. 2, pp. 10720.

ILO (2002a), Decent Work and the Informal Economy, International Labour Office, Geneva.

Krueger, N.F., Jr. (1993). The impact of prior entrepreneurial exposure on perceptions. Entrepreneurship Theory and Practice, 18(1), 5-22.

La Porta, R., and A. Shleifer. 2008. "The Unofficial Economy and Economic Development." NBER Working Paper Series No.14520. Cambridge, MA: NBER.

[http://www.nber.org/papers/w14520].

La Porta, R., Lopez-de-Silanes, F., Shleifer, A., \& Vishny, R.W. (1999). The quality of government. Journal of Law, Economics, and Organization, 15, 222-279.

Lacobucci, D., and P. Rosa. 2010. "The Growth of Business Groups by Habitual Entrepreneurs: The Role of Entrepreneurial Teams." Entrepreneurship Theory and Practice 34 (2): 351-377.

Lee, S. M., \& Peterson, S. J. (2000). Culture, entrepreneurial orientation, and global competitiveness. Journal of World Business, 35(4), 401-416.

Licht, A. N., and J. I. Siegel. 2006. "The Social Dimensions of Entrepreneurship." In M. Casson., B Yeung. A. Basu., and N. Wadeson. The Oxford Handbook of Entrepreneurship. 511-539. New York: OUP.

Llanes, M. and Barbour, A. (2007), Self-employed and Micro-entrepreneurs: Informal Trading and the Journey towards Formalization, Community Links, London.

Low, M. B., and I. C. MacMillan. 1988. "Entrepreneurship: Past research and future challenges." Journal of Management 14 (2): 139-161.

Lumpkin, G. T., and G. G. Dess. 2001. “Linking Two Dimensions of Entrepreneurial Orientation to Firm Performance: The Moderating Role of Environment and Industry Life Cycle." Journal of Business Venturing 16 (5): 429-451.

Madichie, N.O., A. D. Nkamnebe, E. I. Idemobi. 2008. "Cultural determinants of entrepreneurial emergence in a typical sub-Sahara African context." Journal of Enterprising Communities: People and Places in the Global Economy 2 (4): 285-299.

Ngoasong, M.Z. and Kimbu, A.N. (2016). Informal microfinance institutions and development-led tourism entrepreneurship. Tourism Management, 52: 430-

North, D. (1990). Institutions, institutional change, and economic performance. New York: Norton.

Nwabuzor, A. (2005). Corruption and development: New initiatives in economic openness and strengthened rule of law. Journal of Business Ethics, 59, 121-138.

Pretes, M. (2002). Microequity and microfinance. World Development, 30(8), 1341-1353 
Portes, A. \& Haller, W. (2005). The informal economy. In N.J. Smelser \& R. Swedberg (Eds.), Handbook of economic sociology (pp. 403-427). New York: Russell Sage Foundation.

Saunders, M., P. Lewis, and A. Thornhill. 2003. Research Method for Business Students (3rd Edition). New York: Prentice Hall.

Scott, W.R. (2001). Institutions and organizations. London: Sage.

Shane, S., and S. Venkataraman. 2000. "The Promise of Entrepreneurship as a Field of Research." Academy of Management Review 25: 217-226.

Shapero, A. and L. Sokol. 1982. "The Social Dimensions of Entrepreneurship." In The Encyclopedia of Entrepreneurship. 72-90. Englewood Cliffs, NJ: Prentice Hall.

Smith, R. and Christou, M.L. (2009), "Extracting value from their environment: some observations on pimping and prostitution as entrepreneurship", Journal of Small Business and Entrepreneurship, Vol. 22 No. 1, pp. 69-84.

Spencer, J. W. and C. Gomez. 2004. "The Relationship among National Institutional Structures, Economic Factors, and Multidomestic Entrepreneurial Activity: A Multicountry Study." Journal of Business Research 57: 1098-1107.

Taylor, S. J., and R. Bogdan. 1998. Introduction to Qualitative Research Methods: A Guidebook and Resources (3rd Ed.). New York: John Wiley \& Sons.

Spring, A. (2009). African women in the entrepreneurial landscape: Reconsidering the formal and informal sectors. Journal of African Business, 10(1), 11.

Tesfachew, T (1992) "Government policies and the urban informal sector in Africa", (Geneva).

Thomas, R., Shaw, G., \& Page, S. J. (2011). Understanding small firms in tourism: A perspective on research trends and challenges. Tourism Management 32(5), 963-976.

Urban, B. (2005). Influence of the institutional environment on entrepreneurial intentions in an emerging economy. International Journal of Entrepreneurship and Innovation, 14(3), 179

USAID. 2006. "Micro and Small Enterprises, Dynamic Economic Growth and Poverty Reduction: A Review of the Conceptual and Empirical Effects of MSES on Development." Micro Report \#62. Washington DC: USAID.

Webb, J. W., Bruton, G. D., Tihanyi, L., \& Ireland, R. D. (2012). Research on entrepreneurship in the informal economy: Framing a research agenda. Journal of Business Venturing, 28(5), 598-614.

Welter, F., and D. Smallbone. 2011. "Institutional Perspectives on Entrepreneurial Behaviour in Challenging Environments." Journal of Small Business Management 49 (1): 107-125.

Wennekers, S. 2006. "Entrepreneurship at Country Level; Economic and Non-Economic Determinants." Rotterdam:

ERIM. [http://publishing.eur.nl/ir/repub/asset/7982/EPS20060810RG9058921158Wennekers. pdf.]

Wiklund, J., P. Davidsson, D. Audretsch, and C. Karlsson. 2011. "The Future of Entrepreneurship Research." Entrepreneurship Theory and Practice 35 (1): 1-9.

Williams, C.C. (2006), Hidden Enterprise Culture: Entrepreneurship in the Underground 
Economy, Edward Elgar, Cheltenham.

Yin, R. K. 2003. Case Study Research: Design and Methods (3rd Ed.). Thousand Oaks, CA: Sage. 